\title{
In-Source CID of Guanosine: Gas Phase Ion-Molecule Reactions
}

\author{
Robin Tuytten, Filip Lemière, and Eddy L. Esmans \\ Department of Chemistry, Nucleoside Research and Mass Spectrometry Unit and Center for Proteomics \\ and Mass Spectrometry, University of Antwerp, Antwerp, Belgium
}

\author{
Wouter A. Herrebout and Benjamin J. van der Veken \\ Department of Chemistry, Cryospectroscopy, University of Antwerp, Antwerp, Belgium
}

\author{
Ed Dudley and Russell P. Newton \\ Biochemistry Group, School of Biological Sciences and Biomolecular Analysis Mass Spectrometry Facility, \\ University of Wales, Swansea, United Kingdom
}

\section{Erwin Witters}

Department of Biology, Laboratory for Plant Biochemistry and Center for Mass Spectrometry and Proteomics, University of Antwerp, Antwerp, Belgium

In-source collision induced dissociation was applied to access second generation ions of protonated guanosine. The in-source gas-phase behavior of $\left[\mathrm{BH}_{2}\right]^{+}-\mathrm{NH}_{3}\left(\mathrm{~m} / \mathrm{z} 135, \mathrm{C}_{5} \mathrm{H}_{3} \mathrm{~N}_{4} \mathrm{O}^{+}\right)$ was investigated. Adduct formation and reactions with available solvent molecules $\left(\mathrm{H}_{2} \mathrm{O}\right.$ and $\mathrm{CH}_{3} \mathrm{OH}$ ) were demonstrated. Several addition/elimination sequences were observed for this particular ion and solvent molecules. Dissociation pathways for the newly formed ions were developed using a QqTOF mass spectrometer, permitting the assignment of elemental compositions of all product ions produced. Reaction schemes were suggested arising from the ring-opened intermediate of the protonated base moiety $\left[\mathrm{BH}_{2}\right]^{+}$, obtained from fragmentation of guanosine. The mass spectral data revealed that the in-source $\mathrm{CH}_{3} \mathrm{OH}$-reaction product underwent more complex fragmentations than the comparable ion following reaction with $\mathrm{H}_{2} \mathrm{O}$. A rearrangement and a parallel radical dissociation pathway were discerned. Apart from the mass spectrometric evidence, the fragmentation schemes are supported by density functional theory calculations, in which the reaction of the ring-opened protonated guanine intermediate with $\mathrm{CH}_{3} \mathrm{OH}$ and a number of subsequent fragmentations were elaborated. Additionally, an in-source transition from the ring-opened intermediate of protonated guanine to the ring-opened intermediate of protonated xanthine was suggested. For comparison, a low-energy collision induced dissociation study of xanthosine was performed. Its dissociation pathways agreed with our assumption. (J Am Soc Mass Spectrom 2006, 17, 1050-1062) (c 2006 American Society for Mass Spectrometry

$\mathrm{D}$ uring the last decade, most fragmentation pathways were elaborated on triple quadrupole (QqQ) and particularly quadrupole ion-trap (QIT) instruments. The latter's capabilities of accessing $\mathrm{MS}^{\mathrm{n}}$ product ions by applying repeated stages of mass selection and fragmentation proved to be very useful [1]. The maturation of the time of flight (TOF) technology and, more importantly, its use in hybrid-arrangements such as the popular orthogonal QqTOF mass spectrometer made accurate mass data of product ions more readily available [2]. In many cases, the elemental compositions of the product ions can unambiguously be

Published online June 5, 2006

Address reprint requests to Professor F. Lemière, Department of Chemistry, Nucleoside Research and Mass Spectrometry Unit and Center for Proteomics and Mass Spectrometry, University of Antwerp, Groenenborgelaan 171, B-2020 Antwerp, Belgium. E-mail: filip.lemiere@ua.ac.be assigned when using a QqTOF mass spectrometer. Product ions lower in the genealogical ladder are also accessible by applying relatively high collision energies in the collision cell. Yet disentanglement of different dissociation pathways originating from a communal progenitor is -in general-still confined to QIT set ups, although the interpretation of energy resolved spectra also has proven its usefulness [3].

Recently we and others showed [4-6] that by making optimal use of in-source CID, combined with the inherent tandem MS capabilities of the QqTOF, what is in effect up to $\mathrm{MS}^{5}$ data can be acquired. Compared to QIT data the QqTOF data obtained is superior in respect of higher mass accuracy. On the other hand QIT-CID experiments, in general, access almost exclusively the dissociation reaction channels of the lowest energy of activation [7]. This energy-dependent information can 


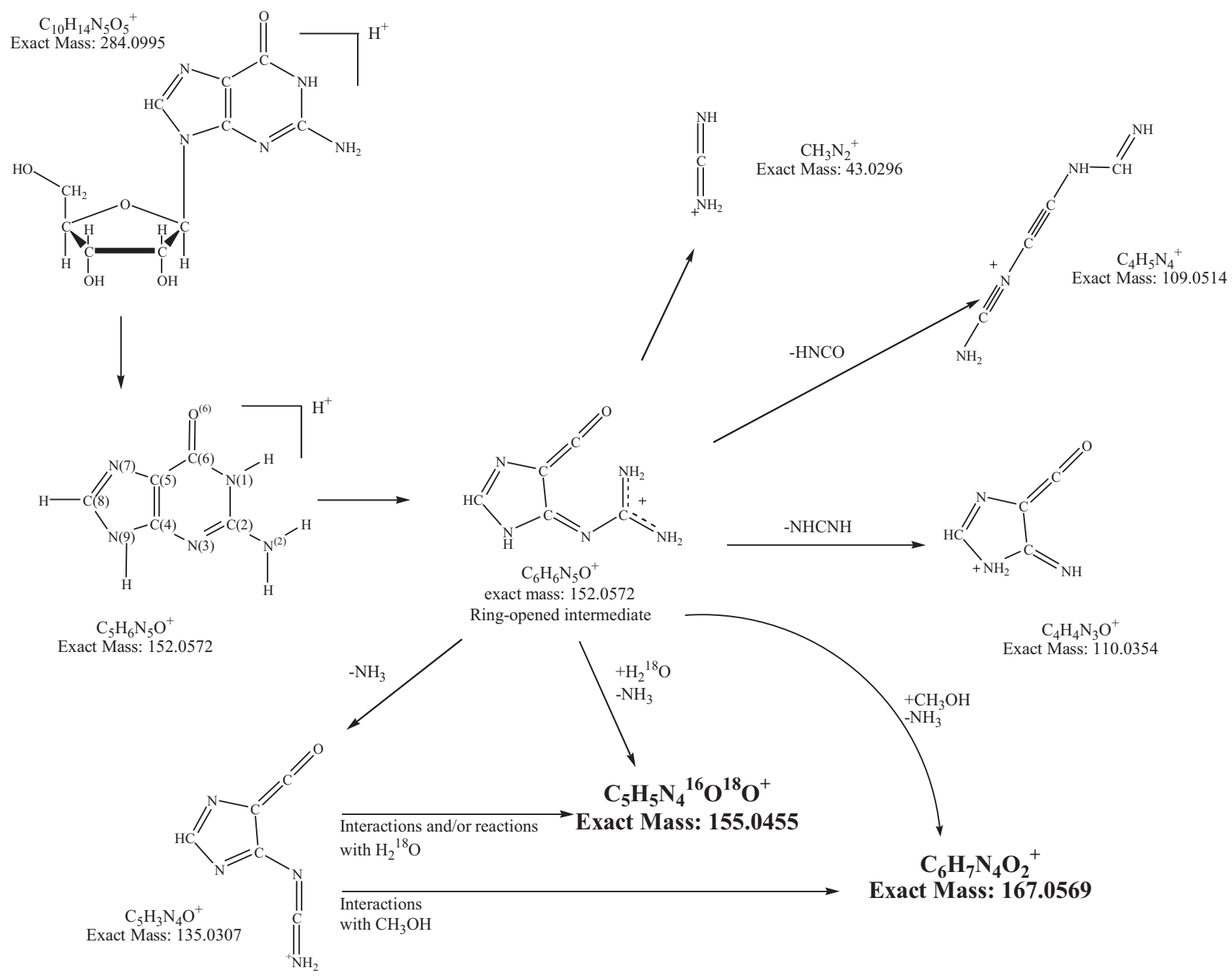

Figure 1. The main dissociation pathways of protonated guanosine up to the second generation product ions, together with the ions at $\mathrm{m} / \mathrm{z} 155$ and 167, respectively, formed upon interaction/ reaction with $\mathrm{H}_{2}^{18} \mathrm{O}$ or $\mathrm{CH}_{3} \mathrm{OH}$. For this study the latter ions were generated in-source by applying adjusted $\mathrm{CV}$-values.

pass unrecognized in QqTOF tandem MS experiments due to a less controlled energy deposit on the parent ions. However, in QqTOF experiments fragmentation pathways with higher activation energies become within reach due to higher energy-transfer in a single collision at high CE settings [6, 7].

During an in-depth study of the fragmentation behavior of the nucleoside guanosine with the optimized in-source CID-QqTOF MS approach it became clear that some of its product ions have a high affinity for $\mathrm{H}_{2} \mathrm{O}$. Additionally, some other product ions arose, which suggested even more sophisticated ion-molecule reactions [5]. It has to be noted that in-source addition of solvent molecules has been observed before by Gabelica et al. for benzylpyridinium cations [8].

This work focuses on these gas-phase ion-molecule interactions and reactions of one particular product ion of protonated guanosine. By in-source CID of the protonated guanosine the second generation product ion
$\mathrm{C}_{5} \mathrm{H}_{3} \mathrm{~N}_{4} \mathrm{O}^{+}$at $m / z 135$ (Figure 1 ), was produced $[5,9]$. Its in-source formed adducts with $\mathrm{H}_{2}{ }^{18} \mathrm{O}$ and $\mathrm{CH}_{3} \mathrm{OH}$ were subsequently submitted to tandem MS analysis by QqTOF MS and accurate mass data of the according product ions was acquired. Different neutral gain/ neutral loss sequences involving $\mathrm{H}_{2} \mathrm{O}$ and $\mathrm{CH}_{3} \mathrm{OH}$ were distinguished.

Based on the product ions, an in-source formation of ring-opened xanthine was predicted, emanating from the reaction with $\mathrm{H}_{2} \mathrm{O}$ of the ring opened protonated guanine. To support this assumption the complete low-energy CID fragmentation study of xanthosine was elaborated.

The product ion data of the $\mathrm{CH}_{3} \mathrm{OH}$ adduct indicated that a reaction of the same ring opened protonated guanine with $\mathrm{CH}_{3} \mathrm{OH}$ occurred. Product ions were observed resulting from the transfer of the methyl group from the methanol to the heterocyclic base. The tentative reaction- and fragmentation schemes deduced 
from the mass spectral data were confirmed by quantumchemical calculations in which theoretical information on the anticipated gas-phase reaction and the ensuing fragmentation pathways were obtained at the DFT level. To this end, equilibrium geometries were obtained starting from the tentative product ion structures, and the reaction energies $\Delta \mathrm{E}_{\mathrm{r}}$ between the reagents/precursor ions and products/fragments were determined. In addition, for all reactions studied, the transition states were localized and the corresponding activation energies were calculated. The results illustrated that for all reactions studied, the theoretical data compared favorably with the tentative schemes. In addition, the DFT calculations provided additional insights with respect to proton positions and the proton transfers.

\section{Experimental}

\section{Chemicals}

Guanosine, xanthosine, and N7-methylguanosine were purchased from Sigma (Bornem, Belgium). ${ }^{18} \mathrm{O}$-labeled water, $\mathrm{H}_{2}{ }^{18} \mathrm{O}\left({ }^{18} \mathrm{O}\right.$, 95\%) was obtained from Cambridge Isotope Laboratories, Inc. (Adover, MA). Methanol, $\mathrm{CH}_{3} \mathrm{OH}$, (HPLC grade), and phosphoric acid, $\mathrm{H}_{3} \mathrm{PO}_{4}$, were acquired from Acros Organics (Geel, Belgium). $\mathrm{H}_{2} \mathrm{O}$ [when the isotope label for oxygen is not mentioned, it is adopted to be ${ }^{16} \mathrm{O}$ ] (HPLC grade) was purchased from Fisher Scientific (Loughborough, Leicestershire, UK). Formic acid, $\mathrm{HCOOH}$, (99-100\%; ultrapure) was obtained from VWR International (Leuven, Belgium).

$1 \mathrm{~mL}$ stock solutions of $10^{-3} \mathrm{M}$ of each nucleoside were prepared in $50 / 50$ ( vol/vol) $\mathrm{CH}_{3} \mathrm{OH} / \mathrm{H}_{2} \mathrm{O}$ or $\mathrm{CH}_{3} \mathrm{OH} / \mathrm{H}_{2}{ }^{18} \mathrm{O}$ (only guanosine). Working solutions were obtained by diluting the stocks further to $10^{-5} \mathrm{M}$ in $50 / 49.9 / 0.1$ (vol/vol) $\mathrm{CH}_{3} \mathrm{OH} / \mathrm{H}_{2} \mathrm{O} / \mathrm{HCOOH}$ or $50 /$ 49.9/0.1 (vol/vol) $\mathrm{CH}_{3} \mathrm{OH} / \mathrm{H}_{2}{ }^{18} \mathrm{O} / \mathrm{HCOOH}$. For this purpose, a $10 \%$ formic acid solution in $\mathrm{H}_{2} \mathrm{O}$ or $\mathrm{H}_{2}{ }^{18} \mathrm{O}$ was used.

\section{Instrumentation and MS Conditions}

A Q-TOF II mass spectrometer (Waters, Manchester, UK) was equipped with a standard pneumaticallyassisted electrospray probe and a Z-spray source (Waters). Electrospray mass spectra were recorded in the positive ion mode. The applied experimental settings were: spray voltage $3.5 \mathrm{kV}$, source temperature $80^{\circ} \mathrm{C}$, and desolvation temperature $100{ }^{\circ} \mathrm{C}$. A cone gas flowrate of ca. $60 \mathrm{~L} / \mathrm{h}$ and a desolvation gas flow-rate of ca. $150 \mathrm{~L} / \mathrm{h}$ were applied. In MS/MS experiments, the precursor ions were selected with an isolation window of $\pm 0.5 \mathrm{Da}$, adequately removing isotopic $\left({ }^{13} \mathrm{C}\right)$ interferences from the spectrum. Scan time and inter-scan time were, respectively $1.0 \mathrm{~s}$ and $0.1 \mathrm{~s}$. For each MS/MS experiment the nucleoside solution was infused for 50 min at a flow rate of $5 \mu \mathrm{L} / \mathrm{min}$ via a syringe pump
Table 1. Applied experimental conditions for the different ionic species subjected to MS/MS

\begin{tabular}{llccc}
\hline & $m / z$ & $C V(V)$ & CE-range (eV) \\
\hline \hline Guo & {$\left[\mathrm{BH}_{2}\right]^{+}-\mathrm{NH}_{3}$} & 135 & 65 & $5-40$ \\
& {$\left[\mathrm{BH}_{2}\right]^{+}-\mathrm{NH}_{3}+\mathrm{H}_{2}{ }^{18} \mathrm{O}$} & 155 & 65 & $5-40$ \\
& {$\left[\mathrm{BH}_{2}\right]^{+}-\mathrm{NH}_{3}+\mathrm{CH}_{3} \mathrm{OH}$} & 167 & 65 & $5-50$ \\
Xan & {$[\mathrm{M}+\mathrm{H}]^{+}$} & 285 & 20 & $5-60$ \\
& {$[\mathrm{BH}]_{2}^{+}$} & 153 & 30 & $5-50$ \\
& {$\left[\mathrm{BH}_{2}\right]^{+}-\mathrm{NH}_{3}$} & 136 & 50 & $5-40$ \\
& {$\left[\mathrm{BH}_{2}\right]^{+}-\mathrm{HNCO}$} & 110 & 65 & $5-40$ \\
\hline
\end{tabular}

(Harvard Apparatus, Natick, MA). During the MS/MS experiment the collision energy was varied in a cyclic manner (5 eV intervals, ranges cf. Table 1) permitting the construction of collision energy profiles. Before the MS/MS experiments of the in-source formed product ions the cone voltage was optimized for each ion of interest. Therefore, a nucleoside solution was infused at $5 \mu \mathrm{L} / \mathrm{min}$ and full scan spectra were recorded $(\mathrm{m} / \mathrm{z}$ 100-600) with a cone voltage varying between 15 and $90 \mathrm{~V}$ (5 V intervals, each $30 \mathrm{~s}$ ). The optimal cone voltage (CV) for each ion of interest was selected upon the evaluation of the extracted ion chromatograms and the corresponding spectra (cf. isobaric interferences).

For high mass accuracy the QqTOF MS was calibrated using $0.1 \%$ phosphoric acid in 50:50 ( $\mathrm{vol} / \mathrm{vol}$ ) $\mathrm{MeOH} / \mathrm{H}_{2} \mathrm{O}$. Any instrument drift was compensated by applying a lock mass correction. Depending on the experiment the protonated nucleoside $[\mathrm{M}+\mathrm{H}]^{+}$, the protonated base $\left[\mathrm{BH}_{2}\right]^{+}$, or other product ions were used as lock mass. In the latter case only these fragments of which the elemental composition was confirmed by us and others were utilized. The TOF analyzer was programmed to record the $\mathrm{m} / \mathrm{z}$ range $50-400$ for the protonated nucleosides and the $\mathrm{m} / \mathrm{z}$ range $50-$ 250 for $\left[\mathrm{BH}_{2}\right]^{+}$and the other ionic species studied. Only nominal masses are given in the discussions, accurate mass data is available in the Supplementary Information, (which can be found in the electronic version of this article).

The data were processed using MassLynx version 3.5. The following criteria were applied to distinguish "true" product ions from interferences in the spectra: (1) only ions with intensity above $1 \%$ of the base peaks intensity were included; (2) the product ions must be present in the spectra for at least two collision energy values applied to any given precursor ion; (3) the product ions must yield credible empirical formulas in respect of the parent ion from which they arose (taking into account possible adduct formation in the collision cell as described previously) $[5,10]$.

\section{Calculations}

Density functional theory (DFT) calculations were performed using Gaussian 03 [11], as installed on the computing cluster CalcUA. Equilibrium geometries and transitions states were obtained at the B3LYP/6-31G(d) 
level. Additional evidence supporting the nature of the stationary was obtained by calculating the corresponding Hessian, and by carefully analyzing the number of imaginary vibrational frequencies derived from them. The Cartesian coordinates, charge distributions, and vibrational frequencies for the geometries obtained are available from the authors upon request.

It should be noted that for the reagent/parent ions and the product ions, computational evidence of donoracceptor interactions between the most electrophilic region of the ions with an electron-rich region of the incoming $\left(\mathrm{CH}_{3} \mathrm{OH}\right)$ or leaving $\left(\mathrm{H}_{2} \mathrm{O}, \mathrm{NH}_{3}, \mathrm{HOCN}\right.$, or $\mathrm{CH}_{3} \mathrm{NH}_{2}$ ) species was found. The appearance of these intermolecular interactions, evidently, influences the calculated energies. In this study, the activation energies and the reaction energies were calculated by comparing the energies of the initial and final adducts, without correcting for the complexation energies present.

\section{Results and Discussion}

\section{$\mathrm{H}_{2} \mathrm{O}$ - and $\mathrm{CH}_{3} \mathrm{OH}$-Adduct Formation of In-Source CID Product ions}

As a starting point of this study a cone voltage (CV) optimization was performed: the $\mathrm{CV}$ was gradually increased while infusing an acidified guanosine solution into the ESI-source. Increasing the CV resulted firstly in a well known break up of the anomeric bond, leading to $\left[\mathrm{BH}_{2}\right]^{+}$. Further $\mathrm{CV}$ increase gave rise to the in-source formation of the initial product ions of the known $\left[\mathrm{BH}_{2}\right]^{+}-\mathrm{NH}_{3}\left(\mathrm{~m} / z \mathrm{z} 135 ; \mathrm{C}_{5} \mathrm{H}_{3} \mathrm{~N}_{4} \mathrm{O}^{+}\right)$and $\left[\mathrm{BH}_{2}\right]^{+}-$ NHCNH pathways $\left(\mathrm{m} / z \mathrm{z} 110 ; \mathrm{C}_{4} \mathrm{H}_{4} \mathrm{~N}_{3} \mathrm{O}^{+}\right)$and the minor $\left[\mathrm{BH}_{2}\right]^{+}$-HNCO $\left(\mathrm{m} / \mathrm{z} 109 ; \mathrm{C}_{4} \mathrm{H}_{5} \mathrm{~N}_{4}^{+}\right)$pathway (Figure 1). Earlier experiments, augmented with DFT calculations, showed that both the $\mathrm{m} / \mathrm{z} 110$ and $\mathrm{m} / \mathrm{z} 135$ product ions interacted strongly with $\mathrm{H}_{2} \mathrm{O}$ present in the source and with traces of $\mathrm{H}_{2} \mathrm{O}$ present in the collision cell [5]. In the latter study, the occurrence of a non-covalent (hydrogen bonded) adduct $m / z 128\left(\mathrm{C}_{4} \mathrm{H}_{4} \mathrm{~N}_{3} \mathrm{O}^{+} \cdot \mathrm{H}_{2} \mathrm{O}\right)$, was derived from the MS/MS-spectra and supported by the DFT calculations. However further characterization of the $\mathrm{m} / \mathrm{z} 153$ due to $\mathrm{C}_{5} \mathrm{H}_{3} \mathrm{~N}_{4} \mathrm{O}^{+} \cdot \mathrm{H}_{2} \mathrm{O}$ with MS/MS revealed several new product ions in addition to the known fragments of $m / z 135$ [5].

Inspection of the full scan spectra clearly illustrated that adduct formation with methanol also occurred for the product ions $m / z 110$ and $m / z 135$. In agreement with earlier observations suggesting that $\mathrm{CH}_{3} \mathrm{OH}$ is a much stronger Lewis base than $\mathrm{H}_{2} \mathrm{O}$, the formation of molecular complexes with $\mathrm{CH}_{3} \mathrm{OH}$ is much more pronounced than with $\mathrm{H}_{2} \mathrm{O}$ (Figure 2). Thus a significant fraction of these, by in-source CID produced, second generation product ions of guanosine was promptly transformed to ions with higher $\mathrm{m} / \mathrm{z}$ ratios. The correlation between the in-source formed product ion at $\mathrm{m} / \mathrm{z} 135$ and its $\mathrm{H}_{2}{ }^{18} \mathrm{O}$ - and $\mathrm{CH}_{3} \mathrm{OH}$-adducts (respectively, at $\mathrm{m} / \mathrm{z} 155$ and 167) is clear from Figure 2: with increasing CV parallel appearances of the $\mathrm{m} / \mathrm{z}$ ratios of $\left[\mathrm{BH}_{2}\right]^{+}-\mathrm{NH}_{3}$, $\left[\mathrm{BH}_{2}\right]^{+}-\mathrm{NH}_{3}+\mathrm{H}_{2}{ }^{18} \mathrm{O},\left[\mathrm{BH}_{2}\right]^{+}-\mathrm{NH}_{3}+\mathrm{CH}_{3} \mathrm{OH}$ occur. Moreover, also in the product ion spectra of the insource formed ion at $m / z 167\left(\mathrm{C}_{5} \mathrm{H}_{3} \mathrm{~N}_{4} \mathrm{O}^{+}+\mathrm{CH}_{3} \mathrm{OH}\right)$, product ions are seen which cannot be explained solely by a noncovalent ion-neutral interaction: gas-phase reactions have to be assumed. In contrast the product ion spectra of $m / z 142,\left(\mathrm{C}_{4} \mathrm{H}_{4} \mathrm{~N}_{3} \mathrm{O}^{+}+\mathrm{CH}_{3} \mathrm{OH}\right)$, shows no other product ions than these corresponding to the initial ions from $m / z 110$.

\section{$\mathrm{C}_{5} \mathrm{H}_{5} \mathrm{~N}_{4}{ }^{16} \mathrm{O}^{18+}$ : A Result of $\mathrm{H}_{2}{ }^{18} \mathrm{O}$-Adduct Formation and $\mathrm{H}_{2}{ }^{18} \mathrm{O}$-Gas-Phase Reactions}

To investigate the phenomena arising from the solventadducts of $m / z 135\left(\mathrm{C}_{5} \mathrm{H}_{3} \mathrm{~N}_{4} \mathrm{O}^{+}\right)$it is favorable to replace $\mathrm{H}_{2}{ }^{16} \mathrm{O}$ by $\mathrm{H}_{2}{ }^{18} \mathrm{O}$ in the sample, since the $\mathrm{H}_{2}{ }^{16} \mathrm{O}$-adduct at $\mathrm{m} / \mathrm{z} 153$ nominally coincides with the natural ${ }^{13} \mathrm{C}$ isotopic signal of the $\left[\mathrm{BH}_{2}\right]^{+}$of guanosine. However, it has to be recognized that considerable amounts of $\mathrm{H}_{2}{ }^{16} \mathrm{O}$ are still present during in-source CID in agreement with the quoted commercial purity of the $\mathrm{H}_{2}{ }^{18} \mathrm{O}$ $\left({ }^{18} \mathrm{O}, 95 \%\right)$ and the atmospheric conditions in the ESIsource.

Application of a cone voltage of $65 \mathrm{~V}$ generated in-source the ion at $\mathrm{m} / \mathrm{z} 135$ together with its $\mathrm{H}_{2}{ }^{18} \mathrm{O}$ adduct at $m / z 155\left(\mathrm{C}_{5} \mathrm{H}_{5} \mathrm{~N}_{4}{ }^{16} \mathrm{O}^{18} \mathrm{O}^{+}\right)$. Both the ions at $\mathrm{m} / \mathrm{z}$ 135 and 155 were monoisotopically selected by the quadrupole filter and accurate mass energy-resolved spectra were collected in the range of 5-40 eV. Exemplary product ion spectra of both ions at $\mathrm{CE} 15 \mathrm{eV}$ and $\mathrm{CE} 30 \mathrm{eV}$ are shown in Figure 3. The accurate mass data confirmed that $m / z 155\left(\mathrm{C}_{5} \mathrm{H}_{5} \mathrm{~N}_{4}{ }^{16} \mathrm{O}^{18} \mathrm{O}^{+}\right)$corresponded with the addition of $\mathrm{H}_{2}{ }^{18} \mathrm{O}$ to $\mathrm{m} / \mathrm{z} 135\left(\mathrm{C}_{5} \mathrm{H}_{3} \mathrm{~N}_{4}{ }^{16} \mathrm{O}^{+}\right)$. The prominent presence of the $m / z 135\left(\mathrm{C}_{5} \mathrm{H}_{3} \mathrm{~N}_{4}{ }^{16} \mathrm{O}^{+}\right)$in the spectra of $\mathrm{m} / \mathrm{z} 155$ at low $\mathrm{CE}$ agrees with the non-covalent nature of the interaction between $\mathrm{C}_{5} \mathrm{H}_{3} \mathrm{~N}_{4}{ }^{16} \mathrm{O}^{+}$and $\mathrm{H}_{2}{ }^{18} \mathrm{O}$. At the same time these spectra demonstrated the stability of the $\mathrm{H}_{2}{ }^{18} \mathrm{O}$-adduct: for $\mathrm{m} / \mathrm{z}$ 155 at CE $15 \mathrm{eV}$ little product ions, apart from $\mathrm{m} / \mathrm{z} 135$, were produced, whereas a fairly extensive fragmentation was apparent at CE $15 \mathrm{eV}$ in the product ion spectrum of $\mathrm{m} / \mathrm{z} 135$ itself. The typical product ions of $\mathrm{m} / \mathrm{z} 135$ only appeared in the product ion spectra of $\mathrm{m} / \mathrm{z}$ 155 at higher CEs. The product ions related with the $\left[\mathrm{BH}_{2}\right]^{+}-\mathrm{NH}_{3}$ pathway have already been discussed [5, 9], but a variety of new product ions were also observed in the MS/MS spectra of $m / z 155$ in the current study. All the product ions associated with the dissociation of $\mathrm{m} / \mathrm{z} 155$ can be found in the Supplementary Materials section, which can be found in the online version of this article.

The product ions of $\mathrm{m} / \mathrm{z} 155$ at $\mathrm{m} / \mathrm{z} 138$ and 137 could not be explained by a simple ion-molecule cluster. The unexpected yet abundant ion at $\mathrm{m} / z 137\left(\mathrm{C}_{5} \mathrm{H}_{3} \mathrm{~N}_{4}{ }^{18} \mathrm{O}^{+}\right)$ is found upon loss of $\mathrm{H}_{2}{ }^{16} \mathrm{O}$ from $\mathrm{m} / z$ 155. The elemental composition of $\mathrm{m} / \mathrm{z} 137$ requires that the ${ }^{16} \mathrm{O}$ originally present in the carbonyl group (C6) of the guanine is 

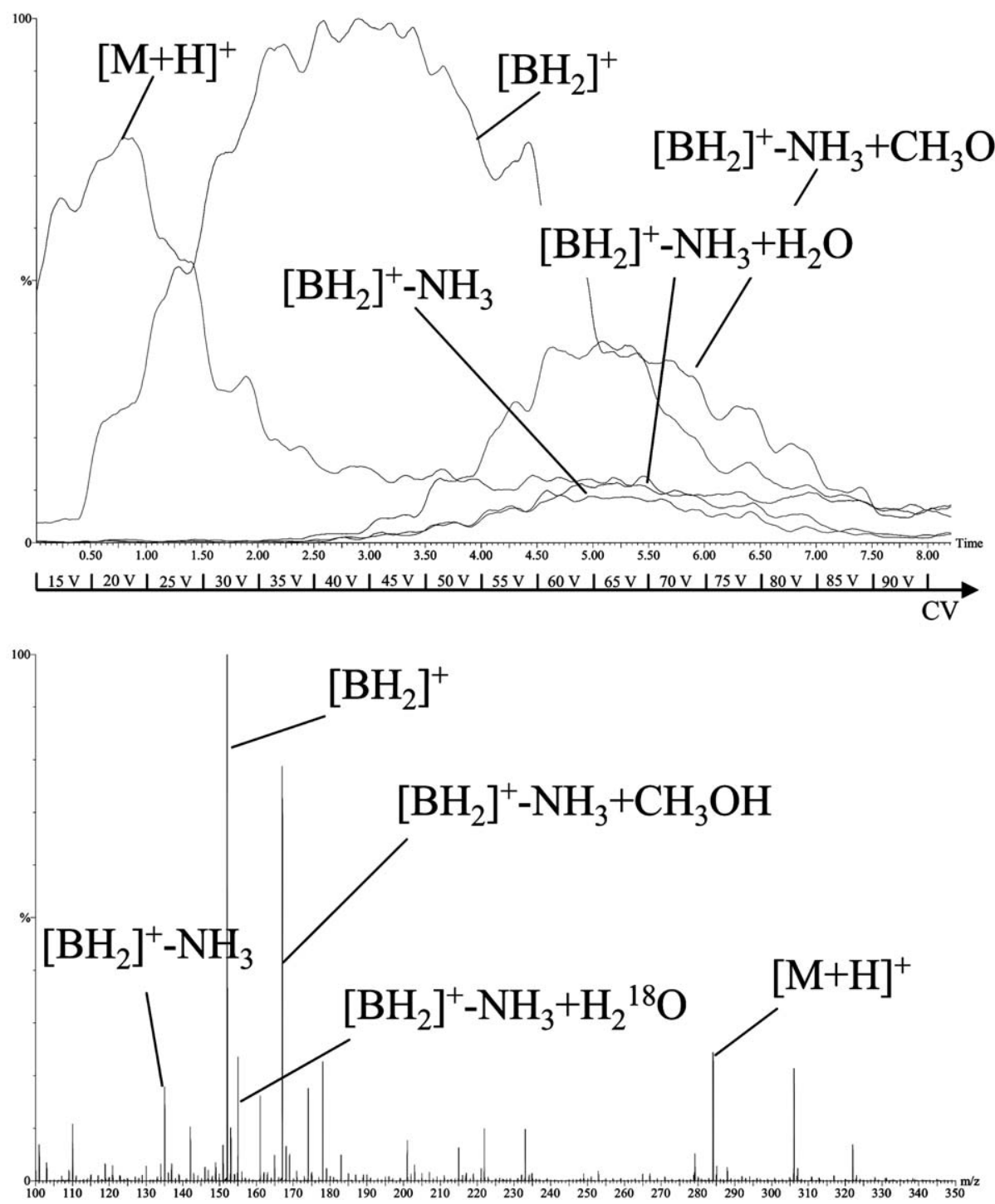

Figure 2. Top: The extracted ion profiles corresponding to the $[\mathrm{M}+\mathrm{H}]^{+},\left[\mathrm{BH}_{2}\right]^{+}$, the $\mathrm{m} / \mathrm{z} 135$ $\left(\left[\mathrm{BH}_{2}\right]^{+}-\mathrm{NH}_{3}\right)$ and the latter's $\mathrm{H}_{2}{ }^{18} \mathrm{O}$ and $\mathrm{CH}_{3} \mathrm{OH}$-adducted ions in function of increasing cone voltage $(\mathrm{CV} ; \mathrm{CV}$ increased $5 \mathrm{~V}$ every $30 \mathrm{~s})$. Bottom: The accumulated spectrum of the $4.5-5.5 \mathrm{~min}$ time span.

removed by formation of the carbonyl hydrate $\left(\mathrm{H}_{2}{ }^{18} \mathrm{O}\right.$, see Scheme 1, and 2,) of $m / z 135$ in-source $(\mathrm{m} / \mathrm{z} 155)$ and dehydration $\left(\mathrm{H}_{2}{ }^{16} \mathrm{O}\right)$ in the collision cell. Further support for this ${ }^{16} \mathrm{O} /{ }^{18} \mathrm{O}$-exchange at $\mathrm{C} 6$ was found in the ion at $m / z 95 \mathrm{C}_{4} \mathrm{HN}_{2}{ }^{18} \mathrm{O}^{+}$. This ion corresponded with the product ion $\mathrm{m} / \mathrm{z} 93\left(\mathrm{C}_{4} \mathrm{HN}_{2}{ }^{16} \mathrm{O}^{+}\right)$, a well characterized fragment of $m / z 135$ [9], which conserves the initial oxygen of $\mathrm{m} / \mathrm{z} 135\left({ }^{18} \mathrm{O}: \mathrm{m} / \mathrm{z} 137\right.$ and $\left.\mathrm{m} / \mathrm{z} 95\right)$. All the other product ions of $\mathrm{m} / \mathrm{z} 137$ coincided with the product ions in the original $\left[\mathrm{BH}_{2}\right]^{+}-\mathrm{NH}_{3}(\mathrm{~m} / z$ 135) pathway since none of them retains the oxygen atom.

The accurate mass data for $\mathrm{m} / \mathrm{z} 138$ pointed to the elemental composition $\mathrm{C}_{5} \mathrm{H}_{2} \mathrm{~N}_{3}{ }^{16} \mathrm{O}^{18} \mathrm{O}^{+}$, which agreed with a loss of $\mathrm{NH}_{3}$. Its interrelationship with $\mathrm{m} / \mathrm{z} 155$ requires a covalently bounded ${ }^{18} \mathrm{O}$ for $\mathrm{C}_{5} \mathrm{H}_{5} \mathrm{~N}_{4}{ }^{16} \mathrm{O}^{18+}$, and not solely a noncovalent ion-molecule interaction. Most likely an addition/elimination reaction occurs at $\mathrm{C}(2)$ of the open-ring intermediate of protonated gua- nine structure proposed by Gregson and McCloskey [9]. A nucleophilic attack by $\mathrm{H}_{2}{ }^{18} \mathrm{O}$ onto the electron deficient $\mathrm{C}(2)$ can result in a subsequent elimination of $\mathrm{NH}_{3}$, leading to the ion at $\mathrm{m} / \mathrm{z} 155$ with the observed elemental composition. A second loss of $\mathrm{NH}_{3}$ from the selected ion $\mathrm{m} / \mathrm{z} 155$ will result in the product ion at $\mathrm{m} / \mathrm{z}$ 138.

Alternatively, a loss of HNCO was easily envisioned from the newly formed ion at $\mathrm{m} / \mathrm{z}$ 155: product ions at $\mathrm{m} / \mathrm{z} 110$ and 112 , depending on the position of the ${ }^{18} \mathrm{O}$-label, were anticipated. Indeed, an ion $\left(\mathrm{C}_{4} \mathrm{H}_{4} \mathrm{~N}_{3} \mathrm{O}^{+}\right)$ was detected as a low abundant ion at $\mathrm{m} / z 112\left({ }^{18} \mathrm{O}\right)$. The ${ }^{16} \mathrm{O}$ analogue at $\mathrm{m} / \mathrm{z} 110$ was not seen since it was obscured by a new abundant ion as explained below. The structure resulting from the loss of $\mathrm{HNCO}$ starting from $\mathrm{m} / \mathrm{z} 155$ was thought to be the same as that emanating from $\left[\mathrm{BH}_{2}\right]^{+}-\mathrm{NHCNH}$ in the fragmentation of guanine [9]. This was confirmed by the presence of 


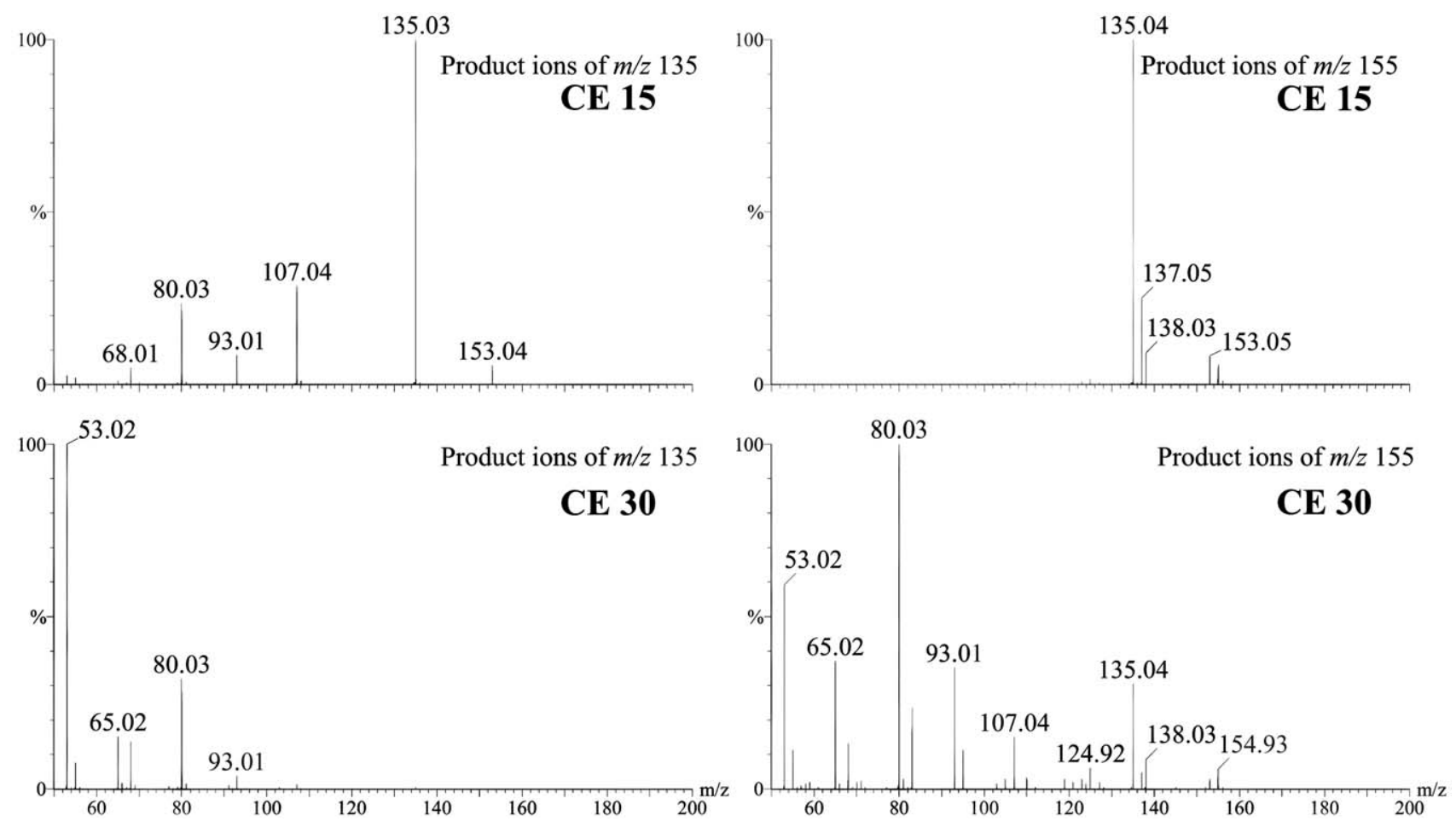

Figure 3. Left: Product ion spectra of the in-source generated ion at $m / z 135\left(\mathrm{C}_{5} \mathrm{H}_{4} \mathrm{~N}_{3} \mathrm{O}^{+}\right)$outgoing protonated guanosine (CV $65 \mathrm{~V}$ and $\mathrm{CE} 15 \mathrm{eV}$ (upper) and $30 \mathrm{eV}$ (lower); no lock mass correction, uncentered). Right: Product ion spectra of the in-source generated ion at $m / z 155\left(\mathrm{C}_{5} \mathrm{H}_{4} \mathrm{~N}_{3} \mathrm{O}^{+}+\mathrm{H}_{2}{ }^{18} \mathrm{O}\right)$ outgoing protonated guanosine (CV $65 \mathrm{~V}$ and $\mathrm{CE} 15 \mathrm{eV}$ (upper) and $30 \mathrm{eV}$ (lower); no lock mass correction, uncentered).

product ions known from the $\left[\mathrm{BH}_{2}\right]^{+}-\mathrm{NHCNH}$ fragmentation pathway resulting from two consecutive losses of $\mathrm{HCN}$, at $\mathrm{m} / \mathrm{z} 85 \mathrm{C}_{3} \mathrm{H}_{3} \mathrm{~N}_{2}{ }^{18} \mathrm{O}^{+}$and $\mathrm{m} / \mathrm{z} 58$ $\mathrm{C}_{2} \mathrm{H}_{2} \mathrm{~N}^{18} \mathrm{O}^{+}$. The corresponding ${ }^{16} \mathrm{O}$ ions were not detected either due to overlapping signals or low signal intensity. Loss of carbon monoxide $\left(\mathrm{C}^{18 / 16} \mathrm{O}\right)$ from $\mathrm{m} / \mathrm{z}$ $112 / 110$ results in the known ion at $\mathrm{m} / \mathrm{z} 82$ which further loses HCN.

Clearly by in-source addition of $\mathrm{H}_{2} \mathrm{O}\left(\mathrm{H}_{2}{ }^{18} \mathrm{O}\right)$ to the $\left[\mathrm{BH}_{2}\right]^{+}-\mathrm{NH}_{3}$ ion and the subsequent loss of $\mathrm{HNCO}$ from $\mathrm{m} / \mathrm{z} 153(\mathrm{~m} / \mathrm{z} 155)$, a blending in of the two major known fragmentation pathways $\left(\left[\mathrm{BH}_{2}\right]^{+}-\mathrm{NH}_{3}(m / z 135)\right.$ and the $\left.\left[\mathrm{BH}_{2}\right]^{+}-\mathrm{HNCNH}(m / z 110)\right)$ occurs, that are normally separate for the fragmentation of protonated Gua $[5,9]$.

In Scheme 2 the other product ions arising from $\mathrm{m} / \mathrm{z}$ 138 are given. The expulsion of $\mathrm{H}^{16 / 18} \mathrm{OCN}$ leads to the pair of product ions at $\mathrm{m} / \mathrm{z} 93 / 95$, with the same elemental compositions as the product ions derived from the ions at $m / z 135$ and $m / z$ 137. An additional loss of carbon monoxide $\left(\mathrm{C}^{16 / 18} \mathrm{O}\right)$ from the ions at $\mathrm{m} / \mathrm{z}$ 93/95 also produces an ion at $\mathrm{m} / z 65\left(\mathrm{C}_{3} \mathrm{HN}_{2}^{+}\right)$which again was common to a product ion appearing in the $\left[\mathrm{BH}_{2}\right]^{+}-\mathrm{NH}_{3}$ pathway. Evidence to support these convergent pathways will follow further. At the same time a second dissociation pathway developed from the ion at $\mathrm{m} / z 138\left(\mathrm{C}_{5} \mathrm{H}_{2} \mathrm{~N}_{3}{ }^{16} \mathrm{O}^{18} \mathrm{O}^{+}\right)$. An initial loss of carbon monoxide $\left({ }^{18 / 16} \mathrm{O}\right)$ led to the ions at $\mathrm{m} / \mathrm{z} 110$ and 108 (very low abundance). From these ions a subsequent loss of $\mathrm{HCN}$ was also observed in the energy resolved spectra giving rise to the unique ions at $\mathrm{m} / \mathrm{z} 83$ and at $\mathrm{m} / \mathrm{z} 81$.

\section{$\mathrm{C}_{6} \mathrm{H}_{7} \mathrm{~N}_{4} \mathrm{O}_{2}^{+}$: A Result of $\mathrm{CH}_{3} \mathrm{OH}$-Adduct \\ Formation and $\mathrm{CH}_{3} \mathrm{OH}$-Gas-Phase Reactions}

As mentioned previously and indicated in Figure 2 a significant fraction of the in-source generated ion at $\mathrm{m} / \mathrm{z}$ 135, ensuing in-source CID of protonated guanosine, was converted into its $\mathrm{CH}_{3} \mathrm{OH}$-adduct $(\mathrm{m} / \mathrm{z}$ 167). It was found interesting to verify if neutral gain/neutral loss sequences similar to those observed for the $\mathrm{H}_{2} \mathrm{O}$-adduct would occur as well for this $\mathrm{CH}_{3} \mathrm{OH}$-adduct. Infusing a Guo solution under the application of a CV of $65 \mathrm{~V}$ produced high levels of the ion at $\mathrm{m} / \mathrm{z} 167$ in-source of which energy resolved spectra were recorded. As there was no isobaric interference there was no need to use isotopic labeled $\mathrm{CH}_{3} \mathrm{OH}$. In Figure 4 the accumulated product ion spectra of $\mathrm{m} / \mathrm{z} 167$ at $\mathrm{CE} 15 \mathrm{eV}$ and $30 \mathrm{eV}$ are shown; additionally the accurate mass data and elemental compositions of all product ions are available in the Supplementary Information. The accurate mass measurement of $m / z 167\left(\mathrm{C}_{6} \mathrm{H}_{7} \mathrm{~N}_{4} \mathrm{O}_{2}^{+}\right)$confirmed the addition of $\mathrm{CH}_{3} \mathrm{OH}$ to $\mathrm{C}_{5} \mathrm{H}_{3} \mathrm{~N}_{4} \mathrm{O}^{+}$.

Noncovalent interaction of methanol with the insource formed fragment at $\mathrm{m} / \mathrm{z} 135$ was indicated by the 


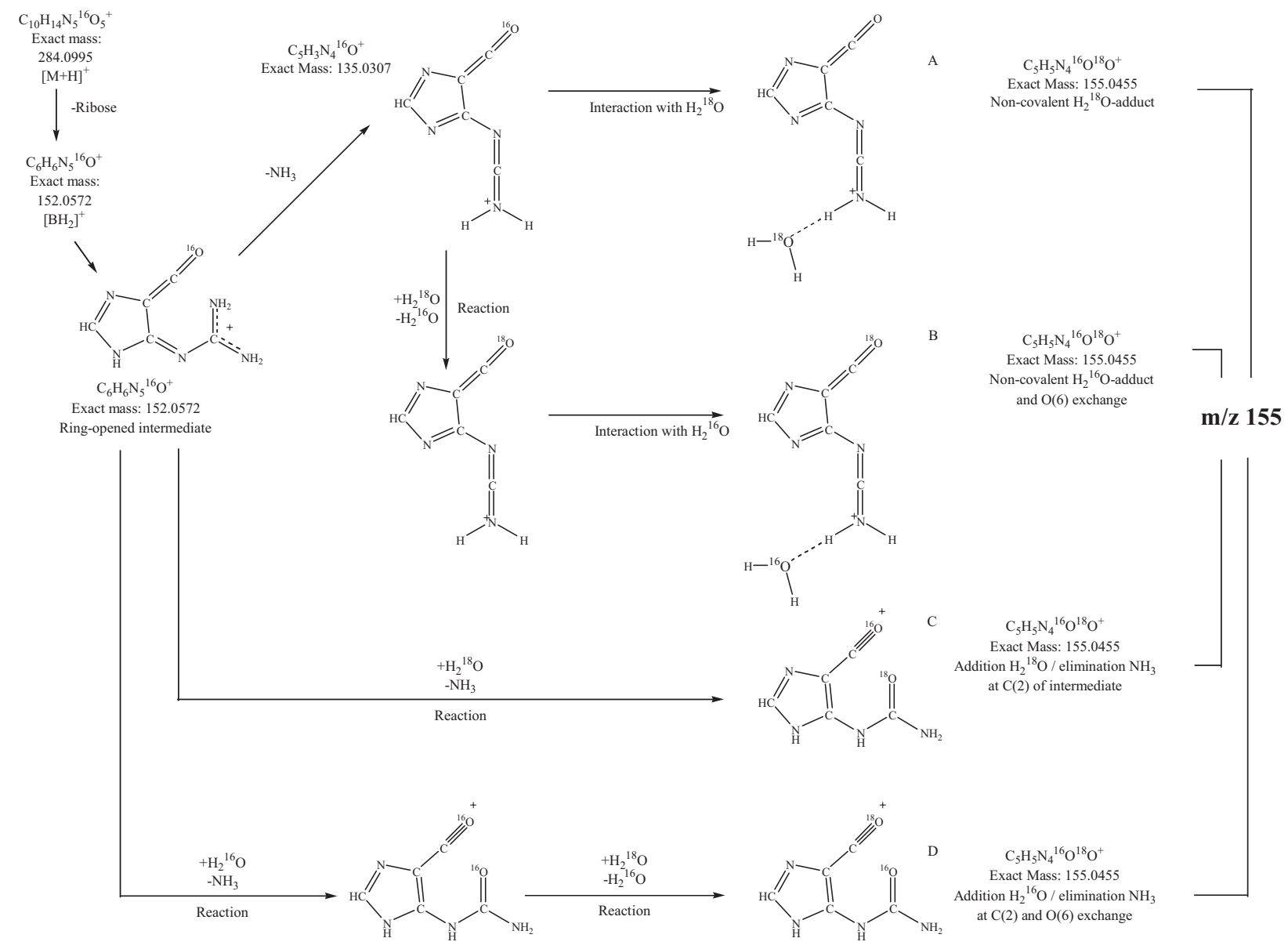

Scheme 1

high abundance of the latter in the product ion spectra of $\mathrm{m} / \mathrm{z} 167$ at low CE. With increased CE, the typical product ions of the $\left[\mathrm{BH}_{2}\right]^{+}-\mathrm{NH}_{3}$ dissociation pathway also appeared. The high affinity of $m / z 135$ for $\mathrm{H}_{2} \mathrm{O}$ is seen in the product ion observed at $m / z 153$, the result of scavenging traces of $\mathrm{H}_{2}{ }^{16} \mathrm{O}$ available in the collision cell by the product ion at $\mathrm{m} / \mathrm{z} 135$ as reported earlier [5].

In analogy with the elimination of $\mathrm{NH}_{3}$ and $\mathrm{HNCO}$ from the $\mathrm{H}_{2}{ }^{18} \mathrm{O}$-adduct $\mathrm{m} / \mathrm{z} 135$, the methanol adduct $m / z 167$ showed the loss of $\mathrm{NH}_{2} \mathrm{CH}_{3}(\mathrm{~m} / \mathrm{z}$ 136) and $\mathrm{CH}_{3} \mathrm{OCN}(\mathrm{m} / \mathrm{z} 110)$, and corresponding product ions derived thereof (Scheme 3). The presence of these ions suggested that also for the adducts with methanol, an addition $\left(\mathrm{CH}_{3} \mathrm{OH}\right)$ /elimination $\left(\mathrm{NH}_{3}\right)$ reaction departing from the ring-opened protonated guanine occurred similar to that observed for $\mathrm{H}_{2}{ }^{18} \mathrm{O}$. Theoretical data obtained from DFT calculations, in which the reagents and the reactions products are studied, confirmed this reaction pathway. The equilibrium geometry of the ring opened intermediate of protonated guanine $(\mathrm{m} / \mathrm{z} 152)$ of the product ion $(\mathrm{m} / \mathrm{z} 167)$ and of typical product ions resulting from further fragmentation of $\mathrm{m} / \mathrm{z} 167$ are summarized in Scheme 4. The transition states involved and the corresponding values for $\mathrm{E}_{\mathrm{a}}$ and $\Delta \mathrm{E}_{\mathrm{r}}$ are collected in Table 2.
The geometry optimizations of protonated ringopened guanine suggested that the positive charge (proton) is preferentially located at the cyanamide moiety rather than at the carbonyl at the (6) position [9]. The DFT results revealed that the addition/elimination reactions are preceded by the formation of a donor: acceptor complex in which an incoming methanol molecule interacts with the ring opened guanine. Subsequently, a concerted reaction takes place: covalent bonding of the oxygen of $\mathrm{CH}_{3} \mathrm{OH}$ at $\mathrm{C}(2)$ proton transfer from $\mathrm{CH}_{3} \mathrm{O}^{*} \mathrm{H}$ to $\mathrm{N}(1) /{ }^{(2)} \mathrm{N}$ and formation of $\mathrm{NH}_{3}$ proceeds in a single step. The transition-state for the concerted reaction, TS1, is shown in Table 2. The corresponding values for $\Delta \mathrm{E}_{\mathrm{r}}$ and $\mathrm{E}_{\mathrm{a}}$ are -1.7 and 223.6 $\mathrm{kJ} \mathrm{mol}^{-1}$. The activation $\left(\mathrm{E}_{\mathrm{a}}\right)$ and reaction energies $\left(\Delta \mathrm{E}_{\mathrm{r}}\right)$ (Table 2) are similar to those obtained for proton transfers [12] and collision induced dissociations [13] in the product ions formation of other nucleosides. The experimental settings, i.e., the collision energy, allow for the calculated transitions.

As the methanol-product was formed with a higher abundance, the product ions $\mathrm{m} / \mathrm{z} 136$ and 110 as well as their fragmentation products were rather easily identified. The loss of methylamine leading to $\mathrm{m} / \mathrm{z} 136$ requires a rearrangement of the ion, in which the methyl 


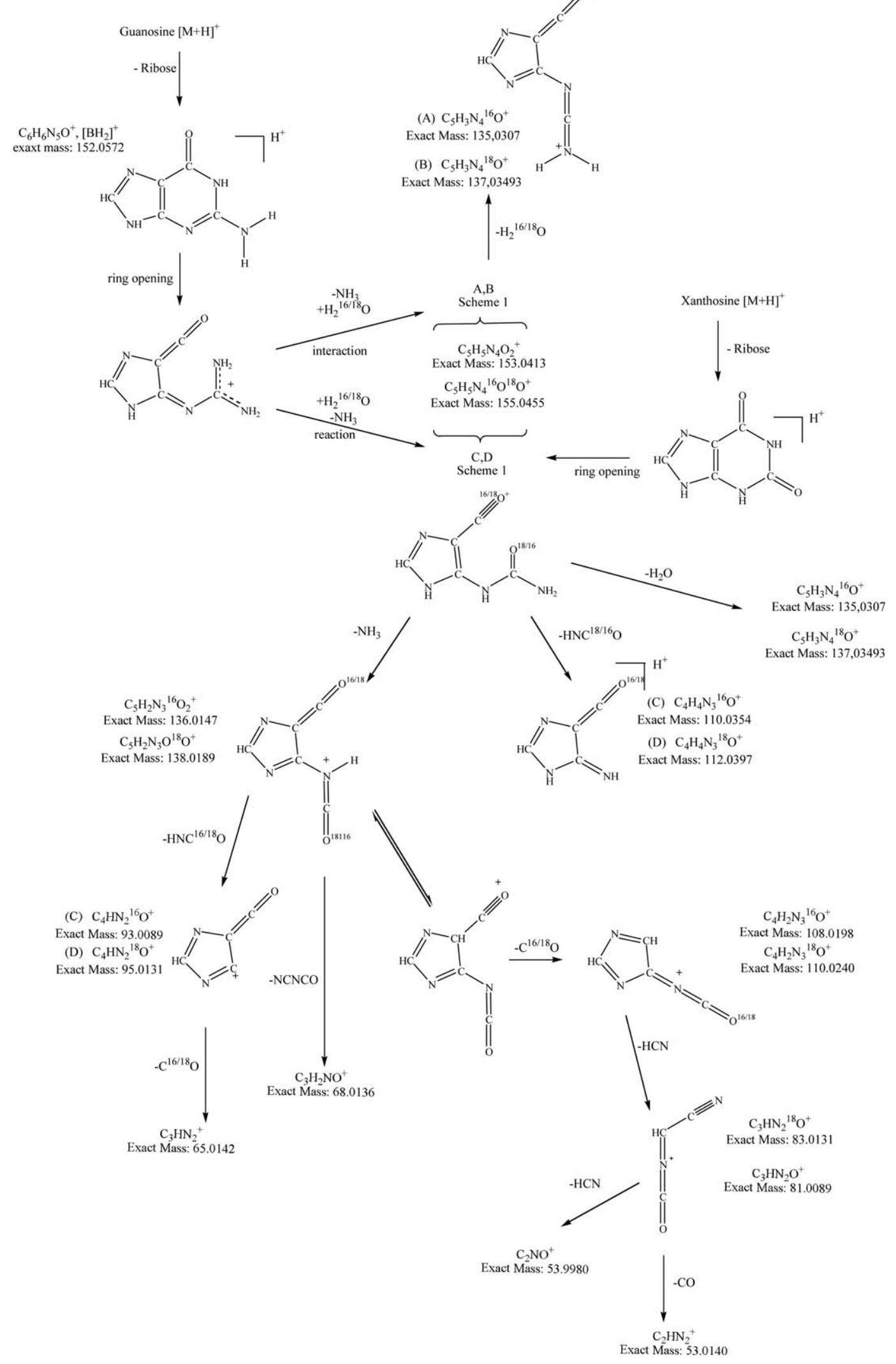

Scheme 2 


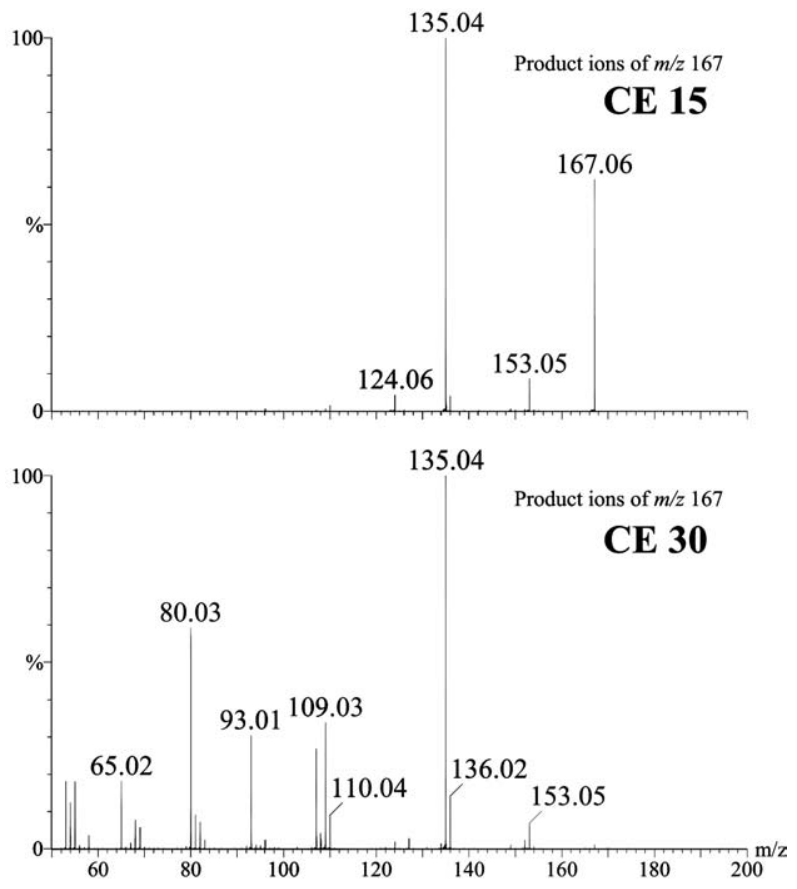

Figure 4. Product ion spectra of the in-source generated ion at $\mathrm{m} / \mathrm{z} 167\left(\mathrm{C}_{5} \mathrm{H}_{4} \mathrm{~N}_{3} \mathrm{O}^{+}+\mathrm{CH}_{3} \mathrm{OH}\right)$ outgoing protonated guanosine (CV $65 \mathrm{~V}$ and $\mathrm{CE} 15 \mathrm{eV}$ (upper) and $30 \mathrm{eV}$ (lower); no lock mass correction, uncentered). group is transferred from the methanol oxygen to the nitrogen $\mathrm{N}(1) /(2) \mathrm{N}$ (cf) randomization of $\mathrm{N}(2) /(2) \mathrm{N}$ subsequent ring-opening [9] (Scheme 3). The occurrence of this transfer is confirmed by the DFT calculations (Scheme 4 and Table 2).

Apart from the features described above, new, less abundant product ions appeared at $m / z 154 \mathrm{C}_{5} \mathrm{H}_{4} \mathrm{~N}_{3} \mathrm{O}_{3}^{+}$, $m / z \quad 152 \quad \mathrm{C}_{5} \mathrm{H}_{4} \mathrm{~N}_{4} \mathrm{O}_{2}^{+}, \quad m / z \quad 150 \quad \mathrm{C}_{6} \mathrm{H}_{5} \mathrm{~N}_{3} \mathrm{O}_{2}^{+}, \mathrm{m} / \mathrm{z} 149$ $\mathrm{C}_{6} \mathrm{H}_{5} \mathrm{~N}_{4} \mathrm{O}^{+}$and $m / z 124 \mathrm{C}_{5} \mathrm{H}_{6} \mathrm{~N}_{3} \mathrm{O}^{+}$. In agreement with the results reported earlier [5], the ion $\mathrm{m} / \mathrm{z} 154$ $\mathrm{C}_{5} \mathrm{H}_{4} \mathrm{~N}_{3} \mathrm{O}_{3}^{+}$resulted from the addition of $\mathrm{H}_{2} \mathrm{O}$ in the collision cell to $\mathrm{m} / \mathrm{z} 136$. The ions $\mathrm{m} / \mathrm{z} 149$ and 150 were assigned to species produced after elimination of $\mathrm{H}_{2} \mathrm{O}$, $\mathrm{NH}_{3}$, and HOCN from the $\mathrm{m} / z 167$ ion.

The latter experimental data are easily rationalized by the obtained equilibrium geometries and transition states derived from the DFT calculations. The elimination of $\mathrm{H}_{2} \mathrm{O}, \mathrm{NH}_{3}$, and HOCN develops via a unique intermediate (VI), which emanates from $\mathbf{V}$ by a methyl transfer from the methanol oxygen to the N(9)position of the original guanine (TS4), followed by a proton transfer (TS5) from VI to VII. Literature and our own (unpublished) mass spectral data further supported the presence of the methyl group on the imidazole ring: product ions at $m / z 149$ and 124 showed to be distinctive for a methyl group positioned on a nitrogen of the imidazole part of a purine (e.g., N7- and N9-methylguanine) [14]. The further eliminations of $\mathrm{H}_{2} \mathrm{O}$ and $\mathrm{NH}_{3}$

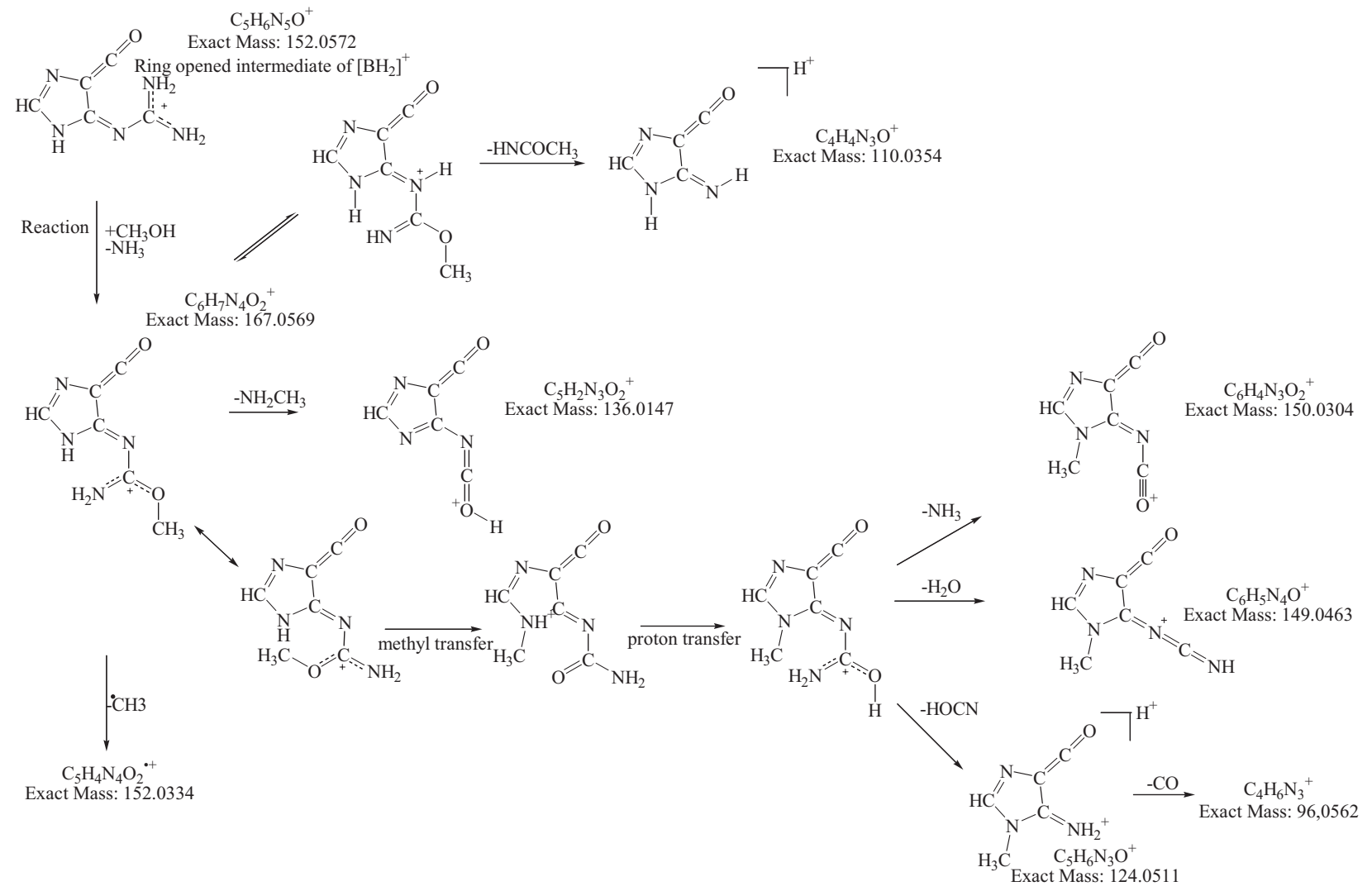




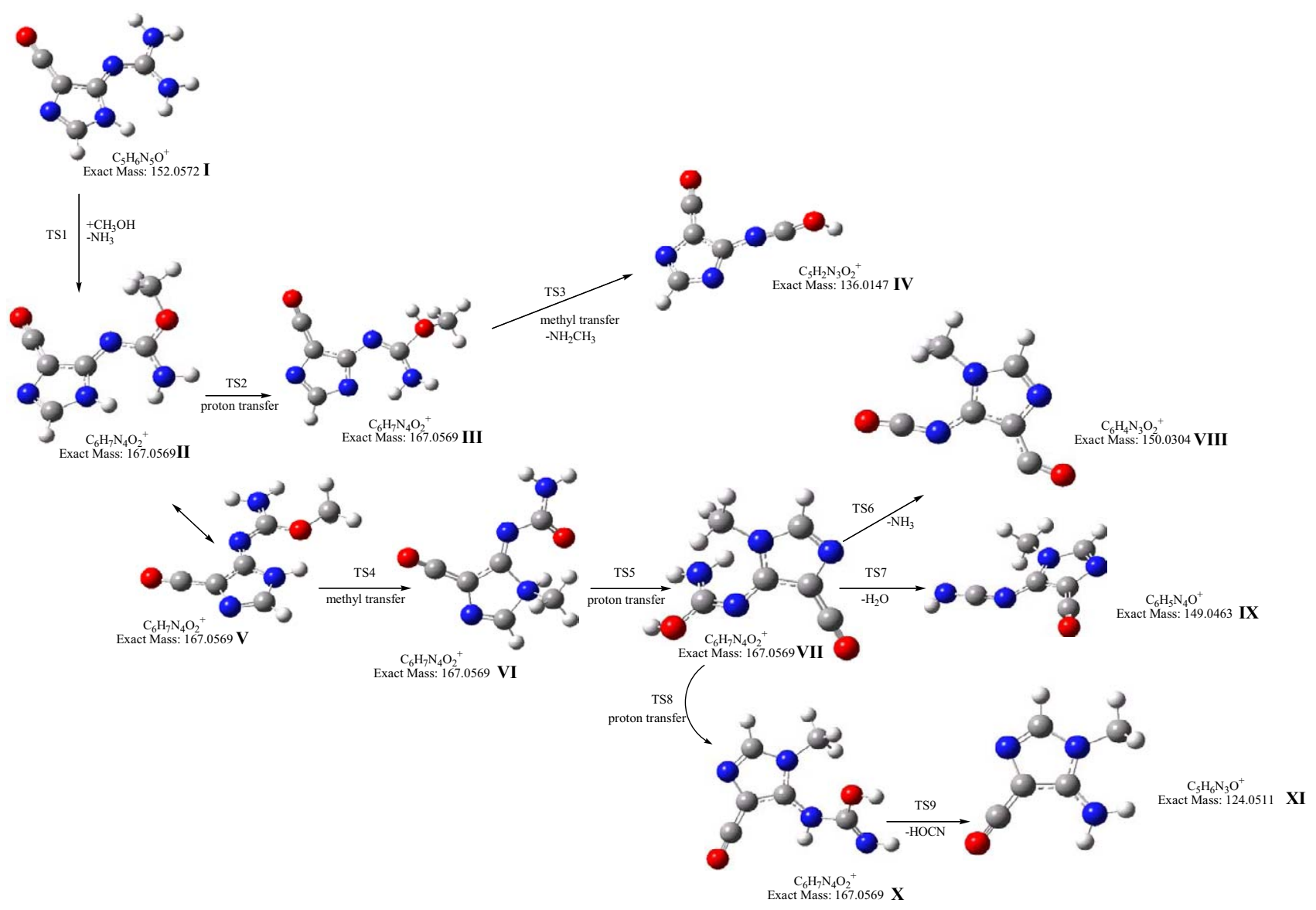

Scheme 4

from VII proceed via a single step, involving either TS7 or TS6. In contrast, the elimination of HOCN requires for two different subsequent proton transfers: a first transfer from VII to $\mathbf{X}$ through TS8 and a second transfer from $\mathbf{X}$ to $\mathbf{X I}$ through TS9 resulting finally in the expulsion of HOCN. An additional product ion at $\mathrm{m} / \mathrm{z} 96\left(\mathrm{C}_{4} \mathrm{H}_{6} \mathrm{~N}_{3}^{+}\right)$corresponded an extra loss of $\mathrm{CO}$ from the ion at $m / z 124$.

Interestingly there also appeared a parallel dissociation pathway comprising only radical product ions in the energy resolved spectra of $\mathrm{m} / \mathrm{z} 167$. This series of radical cations starts off with the loss of a methyl radical from the ion at $\mathrm{m} / \mathrm{z} 167$ to $\mathrm{m} / \mathrm{z} 152 \mathrm{C}_{5} \mathrm{H}_{4} \mathrm{~N}_{4} \mathrm{O}_{2}^{+}$. Two different pathways evolved from there, starting with the loss of $\mathrm{H}_{2} \mathrm{O}$ yielding the ion at $m / z 134\left(\mathrm{C}_{5} \mathrm{H}_{2} \mathrm{~N}_{4} \mathrm{O}^{+\cdot}\right)$ or the loss of HNCO leading to the ion at $\mathrm{m} / \mathrm{z} 109$ $\left(\mathrm{C}_{4} \mathrm{H}_{3} \mathrm{~N}_{3} \mathrm{O}^{+\cdot}\right)$, with the latter being the most abundant. From these two product ions multiple losses of $\mathrm{HCN}$ and/or CO showed, as commonly seen in the dissociation pathways of nucleosides $[5,6,9,15,16]$. It has to be noted that once more an addition of $\mathrm{H}_{2} \mathrm{O}$ in the collision cell was observed; the radical ion at $\mathrm{m} / \mathrm{z} 109$ formed an adduct with $\mathrm{H}_{2} \mathrm{O}$ yielding the radical ion at $\mathrm{m} / \mathrm{z} 127$ $\left(\mathrm{C}_{4} \mathrm{H}_{5} \mathrm{~N}_{3} \mathrm{O}_{2}^{+}\right)$. Many of these radical product ions have nominal masses that coincide with ions of other dissociation pathways (e.g., $\mathrm{C}_{4} \mathrm{H}_{3} \mathrm{~N}_{4}^{+}$calc. $\mathrm{m} / z$ 107.0358,
Table 2. The optimized B3LYP/6-31G(d) transition states of the fragmentation of $\mathrm{m} / \mathrm{z} 167$ as presented in Scheme 4. Energies are given in $\mathrm{kJ} \mathrm{mol}^{-1}$

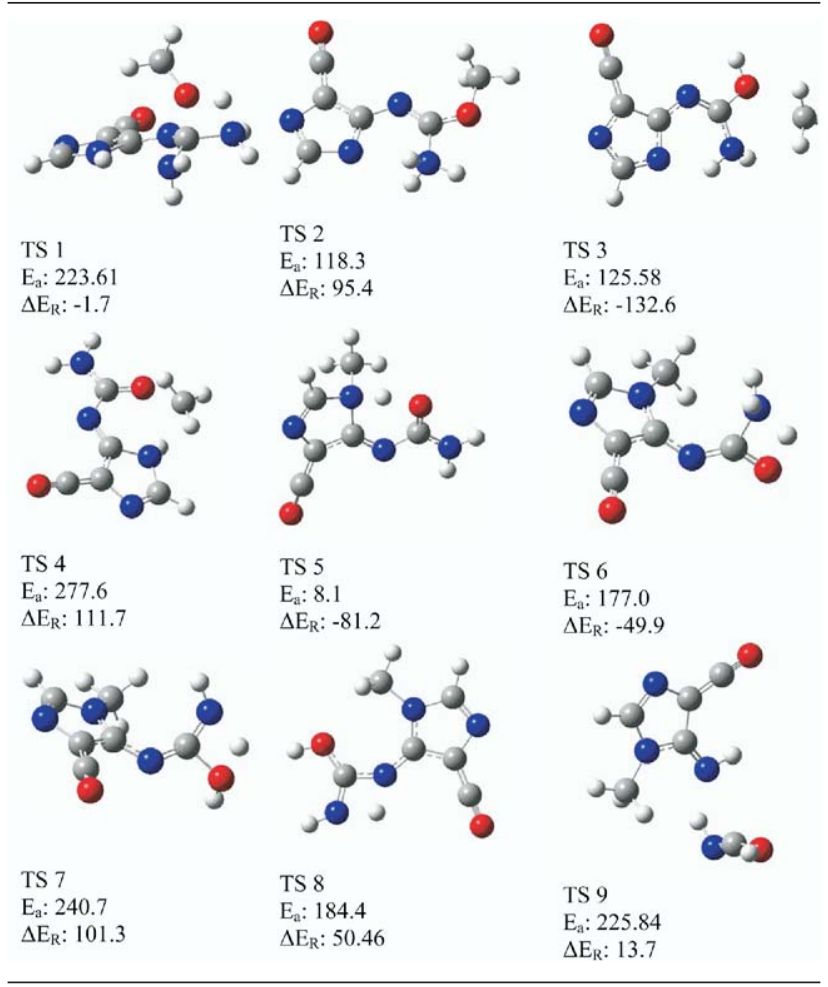



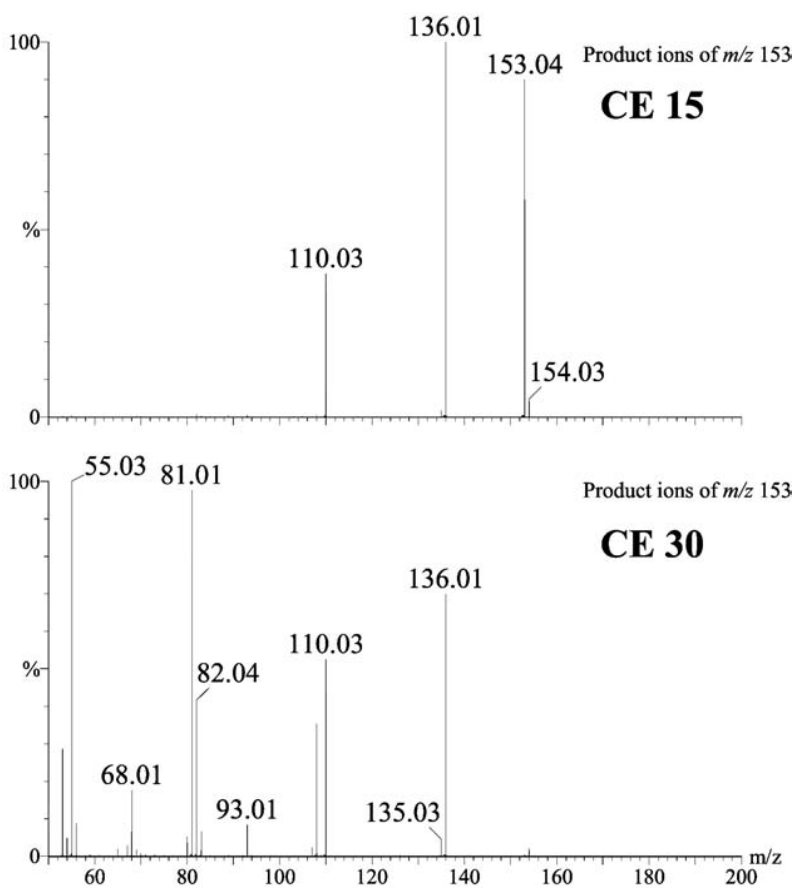

Figure 5. Product ion spectra of the in-source generated $\left[\mathrm{BH}_{2}\right]^{+}$ ion of xanthosine at $\mathrm{m} / \mathrm{z} 153\left(\mathrm{C}_{5} \mathrm{H}_{5} \mathrm{~N}_{4} \mathrm{O}_{2}^{+}\right)(\mathrm{CV} 20 \mathrm{~V}$ and $\mathrm{CE} 15 \mathrm{eV}$ (upper) and $30 \mathrm{eV}$ (lower); no lock mass correction, uncentered).

meas. $m / z 107.0362$ and $\mathrm{C}_{4} \mathrm{HN}_{3} \mathrm{O}^{+}$calc. $\mathrm{m} / \mathrm{z}$ 107.0120, meas. $m / z$ 107.0127). They could only be discerned because of the sufficient resolving power and accuracy of the QqTOF MS.

\section{In-Source Generation of the Ring-Opened Protonated Xanthine}

The hydrolytic deamination of guanine to xanthine is well documented: an enzyme guanine deaminase catalyses the addition of $\mathrm{H}_{2} \mathrm{O}$ and elimination of $\mathrm{NH}_{3}$ [17]. There is a clear similarity with the above described phenomena in the product ion spectra of guanosine. To probe this similarity, an in-depth CID study of the nucleoside xanthosine was performed by means of combined in-source and in-collision cell CID by using the QqTOF mass spectrometer. To the best of our knowledge, no extensive ES-MS fragmentation study of xanthosine has been carried out before.

Initially the energy resolved spectra of protonated xanthosine $[\mathrm{M}+\mathrm{H}]^{+}$were collected between CE 5-60 $\mathrm{eV}$ and based on the accurate mass data elemental compositions assigned (cf. Supplementary Data). Akin to the majority of nucleosides the initial energy deposit caused a break of the anomeric bond. Though unlike other nucleosides an important part of the positive charge was channelled into the sugar-moiety leading to the product ion $\mathrm{S}^{+}$at $m / z 133\left(\mathrm{C}_{5} \mathrm{H}_{9} \mathrm{O}_{4}^{+}\right)$. Further dissociation of this sugar-moiety led to a variety of ions. A plethora of losses of different small neutrals (i.e., water, carbon monoxide, formaldehyde, acetaldehyde) was displayed.
More important to this study was the simultaneous generation of the $\left[\mathrm{BH}_{2}\right]^{+}$ion at $\mathrm{m} / \mathrm{z} 153$, essentially being protonated xanthine $\left(\mathrm{C}_{5} \mathrm{H}_{5} \mathrm{~N}_{4} \mathrm{O}_{2}^{+}\right)$. By applying a $\mathrm{CV}$ of $30 \mathrm{~V}$ the protonated base moiety $(\mathrm{m} / \mathrm{z} 153)$ was formed in-source and its product ion spectra recorded. In Figure 5, the product ion spectra of the protonated xanthine base at CE $15 \mathrm{eV}$ and $30 \mathrm{eV}$ are shown. The protonated xanthine primarily dissociated into the ions at $m / z 136\left(\mathrm{C}_{5} \mathrm{H}_{2} \mathrm{~N}_{3} \mathrm{O}_{2}^{+}\right)$and $m / z 110\left(\mathrm{C}_{4} \mathrm{H}_{4} \mathrm{~N}_{3} \mathrm{O}^{+}\right)$and a minor fragment at $m / z 135\left(\mathrm{C}_{5} \mathrm{H}_{3} \mathrm{~N}_{4} \mathrm{O}^{+}\right)$. These fragments could be rationalized via a ring-opened intermediate of protonated xanthine in analogy to the ring opened protonated guanine (Scheme 2). This ring opened intermediate $(\mathrm{m} / \mathrm{z} 153)$ is identical to the structure following the $\mathrm{H}_{2} \mathrm{O}$-addition/ $\mathrm{NH}_{3}$-elimination on the ring-opened intermediate of protonated guanine. In-source generation of the $\mathrm{MS}^{3}$-like product ions at $\mathrm{m} / \mathrm{z}$ 110 and 136 (respective CVs: $55 \mathrm{~V}$ and $50 \mathrm{~V}$ ) and their subsequent product ions in collision cell CID study supported this conclusion. The plots of the energy resolved spectra of the product ions related to $\mathrm{m} / \mathrm{z} 110$ from protonated xanthine matched exactly the plots of the $\mathrm{m} / \mathrm{z} 110$ originating from protonated guanine (not shown). The further dissociation of the xanthine-fragment at $\mathrm{m} / \mathrm{z} 136$ coincided with the represented pathway (Scheme 2).

In Table 3 a summary of all relevant product ions of the discussed spectra is given, which stresses once more the interrelations between the product ions of $\left[\mathrm{BH}_{2}\right]^{+}$, $\left[\mathrm{BH}_{2}\right]^{+}-\mathrm{NH}_{3}$, and $\left[\mathrm{BH}_{2}\right]^{+}-\mathrm{HNCO}$ of protonated xanthosine and the $\left[\mathrm{BH}_{2}\right]^{+}-\mathrm{NH}_{3},\left[\mathrm{BH}_{2}\right]^{+}-\mathrm{NH}_{3}+\mathrm{H}_{2}{ }^{(18)} \mathrm{O}$ and $\left[\mathrm{BH}_{2}\right]^{+}-\mathrm{NH}_{3}+\mathrm{CH}_{3} \mathrm{OH}$ of protonated guanosine. The absence of some of the predicted product ions in the corresponding product ion spectra of $m / z 135+\mathrm{H}_{2}{ }^{18} \mathrm{O}$ $\left(\mathrm{m} / \mathrm{z} 155, \mathrm{C}_{5} \mathrm{H}_{5} \mathrm{~N}_{4}{ }^{16} \mathrm{O}^{18+}\right)$ is attributed to too low abundances. Clearly, the $\mathrm{m} / \mathrm{z} 155$ ion population was rather limited. Moreover, the signal of $m / z 155$ was composed of several ionic structures and adducts, all fragmenting differently.

\section{Conclusions}

This study demonstrated that in-source CID and product ion spectra thereof must be handled with care, due to the creation of various solvent dependent ionic species. Initial fragment information might be lost as some of the in-source generated product ions might-to greater or lesser extent-be channelled directly into solvent-adducts before their actual MS/MS analysis. The reaction of the product ions with methanol and water occurs both in the electrospray source and, especially for water, also in the collision cell. Depending on the experimental settings, product ions resulting from reaction of guanosine derived ions with $\mathrm{H}_{2} \mathrm{O}$ and $\mathrm{CH}_{3} \mathrm{OH}$ could yield false positive results for the presence of xanthosine and/or methylated guanosines. Similar interactions with solvents might be expected for example for the nucleoside cytidine yielding uridine 
Table 3. Summary of the product ions following the dissociation of the $\left[\mathrm{BH}_{2}\right]^{+}(\mathrm{m} / \mathrm{z} 153),\left[\mathrm{BH}_{2}\right]^{+}-\mathrm{NH}_{3}(m / z 136),\left[\mathrm{BH}_{2}\right]^{+}-\mathrm{HNCO}(m / z$ $110)$ of protonated xanthosine and the product ions of the $\left[\mathrm{BH}_{2}\right]^{+}-\mathrm{NH}_{3}(\mathrm{~m} / \mathrm{z} 135),\left[\mathrm{BH}_{2}\right]^{+}-\mathrm{NH}_{3}+\mathrm{H}_{2}{ }^{18} \mathrm{O}(\mathrm{m} / z 155),\left[\mathrm{BH}_{2}\right]^{+}-\mathrm{NH}_{3}+$ $\mathrm{CH}_{3} \mathrm{OH}(\mathrm{m} / \mathrm{z} 167)$ of protonated guanosine

\begin{tabular}{|c|c|c|c|c|c|c|c|c|c|}
\hline Exact $\mathrm{m} / \mathrm{z}$ & $\begin{array}{c}\text { Elemental } \\
\text { Compositions }\end{array}$ & $\begin{array}{c}\text { Guo m/z } \\
\left(135+\mathrm{H}_{2}^{18} \mathrm{O}\right)\end{array}$ & $\begin{array}{c}\text { Guo m/z } \\
\left(135+\mathrm{CH}_{3} \mathrm{OH}\right)^{\mathrm{b}}\end{array}$ & $\begin{array}{c}\text { Guo } \\
\mathrm{m} / \mathrm{z} \\
135\end{array}$ & $\begin{array}{l}\text { Xan } \\
\mathrm{m} / \mathrm{z} \\
110\end{array}$ & $\begin{array}{l}\text { Xan } \\
\mathrm{m} / \mathrm{z} \\
136\end{array}$ & $\begin{array}{l}\text { Xan } \\
\mathrm{m} / \mathrm{z} \\
153\end{array}$ & $\begin{array}{c}\text { Elemental } \\
\text { Compositions }\end{array}$ & $\begin{array}{l}\text { Nucleoside } \\
\text { Exact } \mathrm{m} / \mathrm{z}\end{array}$ \\
\hline 156.0296 & $\mathrm{C}_{5} \mathrm{H}_{4} \mathrm{~N}_{3}{ }^{16} \mathrm{O}_{2}{ }^{18} \mathrm{O}^{+}$ & $X$ & $\mathrm{X}$ & & & & & $\mathrm{C}_{6} \mathrm{H}_{7} \mathrm{~N}_{4} \mathrm{O}_{2}^{+}$ & 167.0569 \\
\hline $\begin{array}{l}154.0253 \\
155.0455\end{array}$ & $\begin{array}{l}\mathrm{C}_{5} \mathrm{H}_{4} \mathrm{~N}_{3}{ }^{16} \mathrm{O}_{3}{ }^{+} \\
\mathrm{C}_{5} \mathrm{H}_{5} \mathrm{~N}_{4}{ }^{16} \mathrm{O}^{18} \mathrm{O}^{+}\end{array}$ & $X$ & $X$ & $\mathrm{X}$ & & $\mathrm{X}$ & $\mathrm{X}$ & $\mathrm{C}_{5} \mathrm{H}_{4} \mathrm{~N}_{3} \mathrm{O}_{3}{ }^{+}$ & 154.0253 \\
\hline $\begin{array}{l}153.0413 \\
138.0189\end{array}$ & $\begin{array}{l}\mathrm{C}_{5} \mathrm{H}_{5} \mathrm{~N}_{4}{ }^{16} \mathrm{O}_{2}{ }^{+} \\
\mathrm{C}_{5} \mathrm{H}_{2} \mathrm{~N}_{3}{ }^{16} \mathrm{O}^{18} \mathrm{O}^{+}\end{array}$ & $\begin{array}{l}x \\
x\end{array}$ & $X$ & $X$ & & & $\mathrm{X}$ & $\mathrm{C}_{5} \mathrm{H}_{5} \mathrm{~N}_{4} \mathrm{O}_{2}^{+}$ & 153.0413 \\
\hline $\begin{array}{l}136.0159 \\
137.0349\end{array}$ & $\begin{array}{l}\mathrm{C}_{5} \mathrm{H}_{2} \mathrm{~N}_{3}{ }^{16} \mathrm{O}_{2}{ }^{+} \\
\mathrm{C}_{5} \mathrm{H}_{3} \mathrm{~N}_{4}{ }^{18} \mathrm{O}^{+}\end{array}$ & $\begin{array}{l}X^{a} \\
X\end{array}$ & $X$ & $X$ & & $X$ & $X$ & $\mathrm{C}_{5} \mathrm{H}_{2} \mathrm{~N}_{3} \mathrm{O}_{2}{ }^{+}$ & 136.0147 \\
\hline $\begin{array}{l}135.0307 \\
112.0397\end{array}$ & $\begin{array}{l}\mathrm{C}_{5} \mathrm{H}_{3} \mathrm{~N}_{4}{ }^{16} \mathrm{O}^{+} \\
\mathrm{C}_{4} \mathrm{H}_{4} \mathrm{~N}_{3}{ }^{18} \mathrm{O}^{+}\end{array}$ & $\begin{array}{l}X \\
X\end{array}$ & $X$ & $X$ & & & $(\mathrm{X})$ & $\mathrm{C}_{5} \mathrm{H}_{3} \mathrm{~N}_{4} \mathrm{O}^{+}$ & 135.0307 \\
\hline $\begin{array}{l}110.0354 \\
110.0240\end{array}$ & $\begin{array}{l}\mathrm{C}_{4} \mathrm{H}_{4} \mathrm{~N}_{3}{ }^{16} \mathrm{O}^{+} \\
\mathrm{C}_{4} \mathrm{H}_{2} \mathrm{~N}_{3}{ }^{18} \mathrm{O}^{+}\end{array}$ & $\mathrm{X}$ & $X$ & & $X$ & & $\mathrm{X}$ & $\mathrm{C}_{4} \mathrm{H}_{4} \mathrm{~N}_{3} \mathrm{O}^{+}$ & 110.0354 \\
\hline 108.0198 & $\mathrm{C}_{4} \mathrm{H}_{2} \mathrm{~N}_{3}{ }^{16} \mathrm{O}^{+}$ & $\mathrm{X}$ & $X$ & & & $\mathrm{X}$ & $\mathrm{X}$ & $\mathrm{C}_{4} \mathrm{H}_{2} \mathrm{~N}_{3} \mathrm{O}^{+}$ & 108.0198 \\
\hline $\begin{array}{r}107.0358 \\
95.0131\end{array}$ & $\begin{array}{l}\mathrm{C}_{4} \mathrm{H}_{3} \mathrm{~N}_{4}^{+} \\
\mathrm{C}_{4} \mathrm{HN}_{2}{ }^{18} \mathrm{O}^{+}\end{array}$ & $\begin{array}{l}x \\
x\end{array}$ & $\mathrm{X}$ & $X$ & & & $\mathrm{X}$ & $\mathrm{C}_{4} \mathrm{H}_{3} \mathrm{~N}_{4}^{+}$ & 107.0358 \\
\hline $\begin{array}{l}93.0089 \\
85.0288\end{array}$ & $\begin{array}{l}\mathrm{C}_{4} \mathrm{HN}_{2}{ }^{16} \mathrm{O}^{+} \\
\mathrm{C}_{3} \mathrm{H}_{3} \mathrm{~N}_{2}{ }^{18} \mathrm{O}^{+}\end{array}$ & $\begin{array}{l}x \\
x\end{array}$ & $\mathrm{X}$ & $\mathrm{X}$ & & $X$ & $\mathrm{X}$ & $\mathrm{C}_{4} \mathrm{HN}_{2} \mathrm{O}^{+}$ & 93.0089 \\
\hline 83.0245 & $\mathrm{C}_{3} \mathrm{H}_{3} \mathrm{~N}_{2}{ }^{16} \mathrm{O}^{+}$ & & $X$ & & $X$ & & $\mathrm{X}$ & $\mathrm{C}_{3} \mathrm{H}_{3} \mathrm{~N}_{2} \mathrm{O}^{+}$ & 83.0245 \\
\hline $\begin{array}{l}82.0405 \\
83.0131\end{array}$ & $\begin{array}{l}\mathrm{C}_{3} \mathrm{H}_{4} \mathrm{~N}_{3}^{+} \\
\mathrm{C}_{3} \mathrm{HN}_{2}{ }^{18} \mathrm{O}^{+}\end{array}$ & $\begin{array}{l}X \\
X\end{array}$ & $\mathrm{X}$ & & $X$ & & $\mathrm{X}$ & $\mathrm{C}_{3} \mathrm{H}_{4} \mathrm{~N}_{3}^{+}$ & 82.0405 \\
\hline 81.0089 & $\mathrm{C}_{3} \mathrm{HN}_{2}{ }^{16} \mathrm{O}^{+}$ & $X$ & $X$ & & & $X$ & $\mathrm{X}$ & $\mathrm{C}_{3} \mathrm{HN}_{2} \mathrm{O}^{+}$ & 81.0089 \\
\hline $\begin{array}{l}80.0249 \\
69.0089\end{array}$ & $\begin{array}{l}\mathrm{C}_{3} \mathrm{H}_{2} \mathrm{~N}_{3}{ }^{+} \\
\mathrm{C}_{2} \mathrm{HN}_{2}{ }^{16} \mathrm{O}^{+}\end{array}$ & $X$ & $\begin{array}{l}X \\
X\end{array}$ & $X$ & & $\mathrm{X}$ & $\begin{array}{l}X \\
X\end{array}$ & $\begin{array}{l}\mathrm{C}_{3} \mathrm{H}_{2} \mathrm{~N}_{3}^{+} \\
\mathrm{C}_{2} \mathrm{HN}_{2} \mathrm{O}^{+}\end{array}$ & $\begin{array}{l}80.0249 \\
69.0089\end{array}$ \\
\hline $\begin{array}{l}68.0136 \\
68.0253\end{array}$ & $\begin{array}{l}\mathrm{C}_{3} \mathrm{H}_{2} \mathrm{~N}^{16} \mathrm{O}^{+} \\
\mathrm{C}_{2} \mathrm{H}_{2} \mathrm{~N}_{3}^{+}\end{array}$ & $\mathrm{X}$ & $x$ & $\begin{array}{l}X \\
X^{*}\end{array}$ & & $x$ & $x$ & $\begin{array}{l}\mathrm{C}_{3} \mathrm{H}_{2} \mathrm{NO}^{+} \\
\mathrm{C}_{3} \mathrm{H}_{2} \mathrm{~N}^{+}\end{array}$ & $\begin{array}{l}68.0136 \\
68.0253\end{array}$ \\
\hline 67.0296 & $\mathrm{C}_{3} \mathrm{H}_{3} \mathrm{~N}_{2}^{+}$ & & $X$ & & $X$ & & $\mathrm{X}$ & $\mathrm{C}_{3} \mathrm{H}_{3} \mathrm{~N}_{2}^{+}$ & 67.0296 \\
\hline $\begin{array}{l}65.0140 \\
58.0197\end{array}$ & $\begin{array}{l}\mathrm{C}_{3} \mathrm{HN}_{2}^{+} \\
\mathrm{C}_{2} \mathrm{H}_{2} \mathrm{~N}^{18} \mathrm{O}^{+}\end{array}$ & $\begin{array}{l}X \\
X\end{array}$ & $\mathrm{X}$ & $X$ & & $X$ & $\mathrm{X}$ & $\mathrm{C}_{3} \mathrm{HN}_{2}^{+}$ & 65.0140 \\
\hline 56.0136 & $\mathrm{C}_{2} \mathrm{H}_{2} \mathrm{~N}^{16} \mathrm{O}^{+}$ & & $X$ & & $X$ & $X$ & $\mathrm{X}$ & $\mathrm{C}_{2} \mathrm{H}_{2} \mathrm{NO}^{+}$ & 56.0136 \\
\hline $\begin{array}{l}55.0296 \\
53.9980\end{array}$ & $\begin{array}{l}\mathrm{C}_{2} \mathrm{H}_{3} \mathrm{~N}_{2}^{+} \\
\mathrm{C}_{2} \mathrm{NO}^{+}\end{array}$ & $\begin{array}{l}X \\
X\end{array}$ & $\mathrm{X}$ & $X$ & $X$ & $\mathrm{X}$ & $\begin{array}{l}X \\
X\end{array}$ & $\begin{array}{l}\mathrm{C}_{2} \mathrm{H}_{3} \mathrm{~N}_{2}^{+} \\
\mathrm{C}_{2} \mathrm{NO}^{+}\end{array}$ & $\begin{array}{l}55.0296 \\
53.9980\end{array}$ \\
\hline 53.0140 & $\mathrm{C}_{2} \mathrm{HN}_{2}{ }^{+}$ & $\mathrm{X}$ & $\mathrm{x}$ & $X$ & $X^{*}$ & $\mathrm{X}$ & $x$ & $\mathrm{C}_{2} \mathrm{HN}_{2}{ }^{+}$ & 53.0140 \\
\hline
\end{tabular}

(X) Following a transition between different fragmentation pathways ${ }^{a}$ Minor abundance

bOnly product ions shown which are common with the protonated xanthosine- or the $\mathrm{m} / \mathrm{z} 135$ out of protonated guanosine pathways

after hydrolytic deamination and methylated uridine after reaction with methanol.

The unexpected presence of radical cations in the spectra of these protonated molecules further complicates the obtained product ion pattern. High-resolution product ion spectra are required to resolve these radical cations from isobaric even-electron product ions and correct interpretation of the obtained data (Supplementary Material Tables 4, 5, and 6).

\section{Acknowledgments}

Research funded by a Ph.D. grant of the Institute for the Promotion of Innovation through Science and Technology in Flanders (IWT-Vlaanderen). This research was also funded by the Flemish Foundation for Scientific Research (FWO-Vlaanderen), the Flemish Government (GOA), and the University of Antwerp (RAFO). Financial support allowing the purchase of the computer cluster CalcUA was obtained through the "Impulsfinanciering" provided by the Flemish Government. 


\section{References}

1. March, R. E. An introduction to quadrupole ion trap mass spectrometry. J. Mass Spectrom. 1997, 32, 351-369.

2. Chernushevich, I. V.; Loboda, A. V.; Thomson, B. A. An introduction to quadrupole-time-of-flight mass spectrometry. J. Mass Spectrom. 2001, 36 $849-865$.

3. Lemiere, F.; Vanhoutte, K.; Jonckers, T.; Marek, R.; Esmans, E. L.; Claeys, M.; Van den Eeckhout, E.; Van Onckelen, H. Differentiation between isomeric phenylglycidyl ether adducts of 2 '-deoxyguanosine and 2 '-deoxyguanosine-5'-monophosphate using liquid chromatography/electrospray tandem mass spectrometry. J. Mass Spectrom. 1999, 34 $820-834$.

4. Nunez, O.; Moyano, E.; Galceran, M. T. High mass accuracy in-source collision-induced dissociation tandem mass spectrometry and multistep mass spectrometry as complementary tools for fragmentation studies of quaternary ammonium herbicides. J. Mass Spectrom. 2004, 39, $873-883$.

5. Tuytten, R.; Lemière, F.; Van Dongen, W.; Esmans, E. L.; Witters, E.; Herrebout, W.; Van, D.V; Dudley, E.; Newton, R. P. Intriguing mass spectrometric behavior of guanosine under low energy collision-induced dissociation: $\mathrm{H}_{2} \mathrm{O}$ adduct formation and gas-phase reactions in the collision cell. J. Am. Soc. Mass Spectrom.2005, 16, 1291-1304.

6. Dudley, E.; Tuytten, R.; Bond, A.; Lemière, F.; Brenton, A. G.; Esmans, E. L.; Newton, R. P. Study of the mass spectrometric fragmentation of pseudouridine: Comparison of fragmentation data obtained by matrixassisted laser desorption/ionization post-source decay, electrospray ion trap multistage mass spectrometry, and by a method utilizing electrospray quadrupole time-of-flight tandem mass spectrometry and in-source fragmentation. Rapid Commun. Mass Spectrom. 2005, 19, 3075-3085.

7. Sleno, L.; Volmer, D. A. Ion activation methods for tandem mass spectrometry. J. Mass Spectrom. 2004, 39, 1091-1112.

8. Gabelica, V.; Lemaire, D.; Laprevote, O.; De Pauw, E. Kinetics of solvent addition on electrosprayed ions in an electrospray source and in a quadrupole ion trap. Int. J. Mass Spectrom. 2001, 210, 113-119.

9. Gregson, J. M.; McCloskey, J. A. Collision-induced dissociation of protonated guanine. Int. J. Mass Spectrom. 1997, 165, 475-485.

10. Frycak, P.; Huskova, R.; Adam, T.; Lemr, K. Atmospheric pressure ionization mass spectrometry of purine and pyrimidine markers of inherited metabolic disorders. J. Mass Spectrom. 2002, 37, 1242-1248.

12. Turecek, F.; Chen, X. H. Protonated adenine: Tautomers, solvated clusters, and dissociation mechanisms. J. Am. Soc. Mass Spectrom. 2005, 16, 1713-1726.

13. Yao, C. X.; Cuadrado-Peinado, M. L.; Polasek, M.; Turecek, F. Gas-phase tautomers of protonated 1-methylcytosine. Preparation, energetics, and dissociation mechanisms. J. Mass Spectrom. 2005, 40, 1417-1428.

14. Curcuruto, O.; Tarzia, G.; Hamdan, M. Differentiation between isomeric methylated purine derivatives by means of chemical ionization and collision-induced dissociation. Rapid Commun. Mass Spectrom. 1992, 6, 596-600.

15. Nelson, C. C.; McCloskey, J. A. Collision-induced dissociation of uracil and its derivatives. J. Am. Soc. Mass Spectrom. 1994, 5, 339-349.

16. Boos, K. S.; Grimm, C. H. High-performance liquid chromatography integrated solid-phase extraction in bioanalysis using restricted access pre-column packings. TRAC-Trends Anal. Chem. 1999, 18, 175-180.

17. Roberts, E. L. L.; Newton, R. P. Estimation of guanine deaminase using guanosine as a "prosubstrate". Anal. Biochem. 2004, 324, 250-257. 